\title{
man \\ Mainstreaming Urban Agriculture: Opportunities and Barriers to Upscaling City Farming
}

\author{
Michael Hardman*(D), Andrew Clark (D) and Graeme Sherriff (D)
}

check for updates

Citation: Hardman, M.; Clark, A.; Sherriff, G. Mainstreaming Urban Agriculture: Opportunities and Barriers to Upscaling City Farming. Agronomy 2022, 12, 601 https://doi.org/10.3390/ agronomy12030601

Academic Editor: Christine E. H. Coker

Received: 14 January 2022 Accepted: 24 February 2022 Published: 28 February 2022

Publisher's Note: MDPI stays neutral with regard to jurisdictional claims in published maps and institutional affiliations.

Copyright: (C) 2022 by the authors. Licensee MDPI, Basel, Switzerland. This article is an open access article distributed under the terms and conditions of the Creative Commons Attribution (CC BY) license (https:// creativecommons.org/licenses/by/ $4.0 /)$.
School of Science Engineering and Environment, University of Salford, Salford M5 4WT, UK; a.p.clark@salford.ac.uk (A.C.); g.sherriff@salford.ac.uk (G.S.)

* Correspondence: m.hardman@salford.ac.uk

\begin{abstract}
Urban Agriculture (UA), i.e., the production of crops or rearing of livestock in cities, is growing in popularity. Upscaled UA is increasingly gaining support from policy makers, funders, local authorities and other key actors across the globe. Radical forms of the concept, in the form of edible rooftops, urban farms and high-tech growing projects, are becoming more commonplace in our cityscapes; enabling production on a level not witnessed previously. With the mainstreaming of large-scale UA comes the potential to further the social, environmental and economic value of the practice, through job creation, biodiversity enhancement, the creation of short food supply chains and other benefits. Yet, despite this growth, there are barriers to upscaling city farming. Evidence suggests that a core issue surrounds urban soil contamination and hesitation with regards to crops in the city. This paper uses a qualitative approach to explore the UK's largest urban farm and a spectrum of other UA sites to illustrate such barriers. We reveal how public hesitation, financial barriers and soil quality prevent development. We reflect on the breadth of the issue and call for a more pragmatic approach to these barriers. In doing so, we propose a path forward for enabling UA at scale.
\end{abstract}

Keywords: urban agriculture; urban farming; food security; green infrastructure

\section{Introduction: Upscaling Urban Agriculture}

Interest in urban food growing is at an all-time high, with policies and key actors pushing forward the practice across the globe [1,2]. The concept of urban agriculture (UA) is broad and involves a wide range of activities, from traditional allotment gardens to urban farms and increasingly towards technological innovation in food growing [3]. Many spaces go beyond fruit and vegetables, with livestock also featuring on an array of micro and meta-UA sites [4]. Indeed, within the UK and much of Europe, there has been a rise recently in Americanized versions of the practice, with community gardens and other activities emerging. The practice from the USA is more communal in nature, which differs from the UK's individual allotment plot model, and is less restrictive, meaning that more spaces can be created [5]. In this sense, with allotments often over-subscribed, this more communal version of growing has risen in popularity [6].

UA has been thrust into the spotlight during the COVID-19 pandemic, with evidence suggesting that micro and macro sites have stepped up production to meet ever-increasing demands [7]. Even prior to the pandemic, there was a rise in UA policies and plans; with charters, planning documents and other tools being used to enable the practice [8]. Yet, despite this interest and post-pandemic upscaling, there are still a large number of barriers preventing the practice. At the center of these barriers is often contaminated soil, which results in expensive workarounds and alternatives being required to allow for UA to proceed.

This paper provides a critical exploration of the potential of upscaling UA, reflecting on case studies from across the UK, including Northern Roots, the largest urban farm project in the country. We reflect on qualitative data collected across a broad spectrum 
of UA sites; exploring opportunities and barriers to setting up large-scale city farming projects. In doing so, we hope that findings will be of interest to a range of decision-makers, practitioners and academics exploring the potential of UA to contribute significantly to feeding cities.

\section{Feeding the City}

Prior to reflecting on our exploratory work across the UK, we present an overview of UA's role in feeding cities and the current understanding and position of the concept. As with other commentators in this field, we recognize that UA can never feed cities alone, but rather the practice adds value to the existing food system [2]. UA can reduce pressure on conventional rural agriculture, whilst allowing for city residents to be more connected with the food they consume. Whilst we have seen a growth in conventional UA systems, more recently there has been a rise in interest in more radical alternatives, such as edible walls and roofs, underground growing and even cattle farming on urban waterways [9].

\subsection{Conventional $U A$}

Allotments, community gardens, urban farms and other forms of 'conventional' UA are gaining more attention [10]. Studies have shown that these assets provide considerable social, environmental and economic value to urban communities [11]. In the UK, the wider urban and care farming sector employs over 5000 people, turns over $>£ 80,000,000$ a year, engages 40,000 volunteers and supports 15,000 vulnerable people each week [12]. Alongside these considerable impacts, a key focus of late has been around the health and wellbeing value of these sites. In a recent meta-analysis of the health benefits of growing spaces, [13] argue that UA spaces can have significant impacts in this arena. The study reveals a range of benefits where patients are involved in regular interactions with these sites, from helping dementia patients to sleep better to increasing lung capacity in asthma patients leading to reductions in hospital admissions [13].

In the UK, there has been a considerable rise in funding and efforts to expand UA: from DEFRA's upscaling social prescribing fund, to charities and other actors also financing the concept [14-16]. This has resulted in a rise in more urban-based food policy councils, such as the Manchester Food Board, Birmingham Food Policy Council, the Urban Agriculture Consortium, and an array of other bodies at various scales [17]. Despite the increase in such organizations, their development is often hampered by competition for resources, internal politics and limited funding [1]. As [1] describes, these are often short-lived initiatives and, if not coordinated correctly, can result in disruption to communities. Adding to this, newer forms of UA, such as community gardens and urban farms, are not protected by legislation and often face closure [1,2]; allotments on the other hand, in the UK, are highly protected spaces and difficult to remove once established [9].

Further afield, ref. [3] shows how UA policies have enabled practice to flourish, particularly in North America. In this context, newer forms of the concept, such as urban farms and rooftop growing, are argued to be more mainstreamed than anywhere else globally [9]. The likes of New York City, Portland, Toronto and other cities are famed for their abundance of UA and forward-thinking policies [4]. In the Global South, we are also witnessing a rise in the practice, with rooftop growers in the likes of Cape Town and other forms of UA becoming more commonplace [9].

\subsection{High-Tech Growing}

More recently, technology has enabled produce to be grown in higher yields and this has been met with a large amount of interest by a range of actors [18]. Where interest in UA has grown, much of this has been focused on the potential to upscale practice: growing or rearing livestock at scale within urban environments. At the center of this upscaling revolution is the high-tech movement, often involving hydroponics, a system which enables growing in sand or liquid, but not soil [19], aquaponics, a system which uses fish waste to grow produce [20], or aeroponics, a system using vapor to enable crops to grow [21]. 
According to [22], there has been a steady rise in the use of these technologies, with UA projects exploring opportunities for generating more income through increased yield. A key component of these technologies is the perception that yield can be increased, even in the dense urban environment [22]. The systems also offer opportunities to bypass issues around land contamination [23], lack of space in cities [24] and other barriers affecting conventional UA [25].

Key issues of high-tech growing include the often financially unsustainable models adopted, lack of opportunities for older populations and the removal of a connection with nature [26]. Nevertheless, as [27] argues, major players, from supermarkets to developers and the wider private and public sectors have invested heavily in the practice. The authors show how high-tech UA is viewed as a business opportunity, with the likes of Amazon, the Musk family and other high-profile companies starting up farms globally [27]. In the UK, the industry has grown rapidly too, with the likes of Farm Urban, Sow the City, the Bristol Fish Project, the Biospheric Foundation and others joining the race.

\subsection{UA in the UK}

Alongside the rise of policies and UA practice in the UK, there has been a considerable rise in large-scale UA. The aforementioned Biospheric Foundation was a pioneer here, linking high-tech UA production with a nearby shop, aptly named ' 78 steps' due to its short distance from the project [28]. The scheme operated for several years, but reportedly collapsed due to issues surrounding the business model [28]. Linked to this, one of the first large-scale vertical farms in the UK was developed in Wigan; costing over $£ 1$ million, the scheme was linked to the technical college and designed to revolutionize the local food system [29]. However, with the collapse of the attached technical college, the vertical farm quickly fell into disrepair and the scheme ceased to exist. In other cases, large-scale UA schemes have been reduced in size or stripped back, due to an over-reliance on grants and other inconsistent funding sources [9]. These failures emphasize the need to develop long-term sustainable business models to ensure effective implementation of projects.

Despite this often negative result of pioneering projects aiming to upscale UA, there is hope. A key exemplar here are projects like The Kindling Trust, Sandwell Market Garden and the Sustainable Places network, which provide exemplars of sustained upscaled UA. Adding to this, and central to this paper, is Northern Roots based in Oldham, which is soon to be the UK's largest urban farm [30]. The project received a share of funding from the UK Government of $£ 24.5$ million; enabling the scheme to construct a visitor center and upscale current UA operations [31]. The project aims to transform one of England's most deprived towns through UA acting as a catalyst. Benefits are argued to range from the creation of a short-food supply chain, to job creation in the urban farming sector and an array of other positives for the Oldham community [32]. The project also aims to act as a key eco-tourism scheme, through drawing outside footfall into the area [32].

Indeed, much like Northern Roots, there has been a steady rise in 'radical UA' within the UK $[4,8]$. Edible rooftops are gaining in popularity, with more intensive methods being sought to use such leftover space for food production [33]. These previously unused spaces can reinvent the urban environment and bring more benefits, besides increased production: with energy savings, flood management, habitat creation and urban cooling effects also arising from these forms of UA [34-36]. Nevertheless, as [37] argues, the social benefits are often lacking, with the vast majority of edible rooftops not open to members of the public, due to issues around safety and general accessibility.

\subsection{Key Issues Moving Forwards}

Despite the rise in both conventional and radical UA in the UK, key barriers still exist around funding, political support and soil quality $[4,8]$. There are also concerns around the public perception of growing crops, at scale, in the urban context [12]. Yet as interest in UA grows, this appears to be dwindling, with recent studies such as [38], showing that passion for the concept is growing in certain parts of the world. In the Global South for instance, we 
are witnessing more tools to support formal UA and to move away from informal models of production in cities [9]. This in turn leads to safer practices and avoids issues around soil contamination, particularly in townships or other slum-type settlements [23].

Another core issue in the literature surrounds the scale of UA at present. Many UA projects are small-scale in nature, with evidence showing that large-scale ventures have often failed due to poor business models, a lack of community buy-in or other related issues [9]. Indeed, whilst much of this paper focuses on the Global North context, the very concept of upscaled UA in the Global South could perhaps be an issue: adding to the problem of rural to urban migration in some countries, with young farmers attracted by job prospects in ever-growing cities [39]. In this sense, the literature shows that we need to be conscious of the models of UA which are being encouraged and to consider the context in which they are situated before supporting activity.

We now proceed to provide an exploration of upscaled UA in the UK. Large-scale UA is gaining attention, with funding and policy support enabling the concept. Yet despite this, there is a key gap in knowledge around the opportunities and barriers related to varying forms of urban farming. This study draws on qualitative data from a range of exemplar projects across the UK to enable a reflection on the state of the sector; we then combine the primary data with secondary materials to provide a meta overview of the positives and negatives related to various models of upscaled urban farming.

\section{Methodology}

This paper employs a qualitative approach to exploring urban farming practices in the UK. The data collection involved exploring a spectrum of urban farming sites and key actor experts. In this sense, we class urban farms as a larger form of UA, with sites often employing people and having a greater focus on food production [40]. For the purposes of this paper, we adopt [41]: 5's definition of urban farming: 'an urban farm is an intentional effort by an individual or a community to grow its capacity for self-sufficiency and well-being through the cultivation of plants/animals'.

Table 1 provides an overview of urban farms visited as part of the first phase of data collection. The sites range from conventional urban farms, with a core focus on fruit and vegetable production, to larger sites practicing high-tech growing methods. Site selection also included those with meat production, to enable a fair reflection of the range of models being practiced within the UK.

This spectrum of sites, alongside Grounded Theory's Point of Saturation, was used as a tool to justify the sample size [42]. The core aim was to provide a broad overview and baseline understanding of current practices. Semi-structured interviews were employed as the main tool, alongside observations when visiting the sites across the UK. The core aim here was to explore key opportunities and barriers with practice, particularly given the large amount of interest in the concept. The approach enabled the views of the urban farmers, alongside the perspective of the research team to be reflected in the analysis, allowing for a somewhat objective critical view of the activities. Responders were anonymized, although sites were identified in accordance with the informed consent process. Adding to the site-specific discussions, engagement with urban farming key actors, such as the Director of the national charity, added further to the results of this study. In total, some 10 additional experts were interviewed as part of this study, with long-term advocates of UA, planners and a range of other actors adding to the site explorations. This enabled for a more holistic and critical lens of the practice, alongside the semi-structured interviews with farmers and observational elements of the study; providing some balance to the subjective opinions of the urban farming practitioners.

The spectrum of sites captured showcases new advances in urban farm models, alongside more traditional approaches. Adding to this, recent trends, such as the use of UA sites in social prescribing models, were also captured through exploring the range of sites highlighted in Table 1. This activity is often used as a tool to generate more funding for sites, with a rapid rise in urban farms now offering social prescription services [43]. In 
doing so, we provide a meta overview of advances in practice, attempts to upscale and lessons to be learned as more investment is put into urban farming activities. The core aim was to provide a flavor of opportunities and barriers across the spectrum of urban farming practices, with the hope to influence more in-depth critical engagement with the concept.

Table 1. The spectrum of urban farms explored.

\begin{tabular}{|c|c|c|}
\hline Urban Farm & Core Activities & Type \\
\hline Farm Urban & $\begin{array}{ll}- & \text { Hydroponics } \\
- & \text { Aquaponics } \\
- & \text { Sale of produce } \\
- & \text { Education }\end{array}$ & High-tech \\
\hline Salop Drive Market Garden & $\begin{array}{ll}\text { - } & \text { Sale of produce } \\
\text { - } & \text { Education } \\
\text { - } & \text { Apprenticeships/traineeships } \\
\text { - } & \text { Social prescribing }\end{array}$ & Market garden \\
\hline Woodbank Urban Farm & $\begin{array}{ll}- & \text { Sale of produce } \\
\text { - } & \text { Education } \\
\text { - } & \text { Apprenticeships/traineeships } \\
\text { - } & \text { Social prescribing }\end{array}$ & Cooperative farm \\
\hline $\begin{array}{l}\text { Wythenshawe } \\
\text { Community Farm }\end{array}$ & $\begin{array}{ll}\text { - } & \text { Sale of produce } \\
\text { - } & \text { Rearing of livestock for meat } \\
\text { - } & \text { Animal-assisted therapy } \\
\text { - } & \text { Social prescribing }\end{array}$ & $\begin{array}{l}\text { Social farm with meat } \\
\text { production }\end{array}$ \\
\hline Woodgate Valley & $\begin{array}{ll}\text { - } & \text { Social prescribing } \\
\text { - } & \text { Animal-assisted therapy }\end{array}$ & $\begin{array}{l}\text { Social farm without } \\
\text { meat production }\end{array}$ \\
\hline Northern Roots & $\begin{array}{ll}- & \text { Sale of produce } \\
- & \text { Social prescribing } \\
- & \text { Animal-assisted therapy } \\
- & \text { Large-scale visitor attraction }\end{array}$ & $\begin{array}{l}\text { Upscaled } 160 \text { acre urban } \\
\text { and peri-urban farm }\end{array}$ \\
\hline
\end{tabular}

\section{Results and Discussion}

We now proceed to review the core themes from the qualitative exploration of urban farming, firstly by exploring the operations of the spectrum of sites investigated before assessing the barriers and opportunities with upscaling practice. As highlighted in the background section of this paper, there has been an exponential rise in interest in largescale urban farming, with more funding, policy support and general acceptance of the practice each year [43]. We are seeing a shift in practice from the informal to formal in the Global South [23], whilst in the UK, we have witnessed significant funding from central Government, charities, local authorities and even the private sector [31]. This demonstrates the need for more critical investigations into this area, to explore the type of practice which should be encouraged, models to be used and how we can upscale successfully. This paper provides an initial insight into a critical evaluation of practice and hopes to act as a catalyst for further investigation.

\subsection{Growing Urban Farming}

Our research adds to Section 2 by showing that large-scale urban farming is not new, but is growing in popularity. Indeed, several of the farms shown in Table 1 have been operating for many years: 'It's been established for 30 years. I think it was opened 30 years last year' (Woodgate Valley Urban Farm) 'Over 30 years' (Wythenshawe Urban Farm) 'a good 20 years or so' (Salop Drive) 'I coordinated an urban farm for 15 years' (Past Urban Farmer). Figure 1 provides a snapshot of these urban farms and how they differ in terms of their purposes. We argue that the core growth has been in urban farms featuring a more 
explicit business model or set of radical activities, with the likes of Farm Urban and The Kindling Trust upscaling practice through creative means such as hydroponics or social prescription.

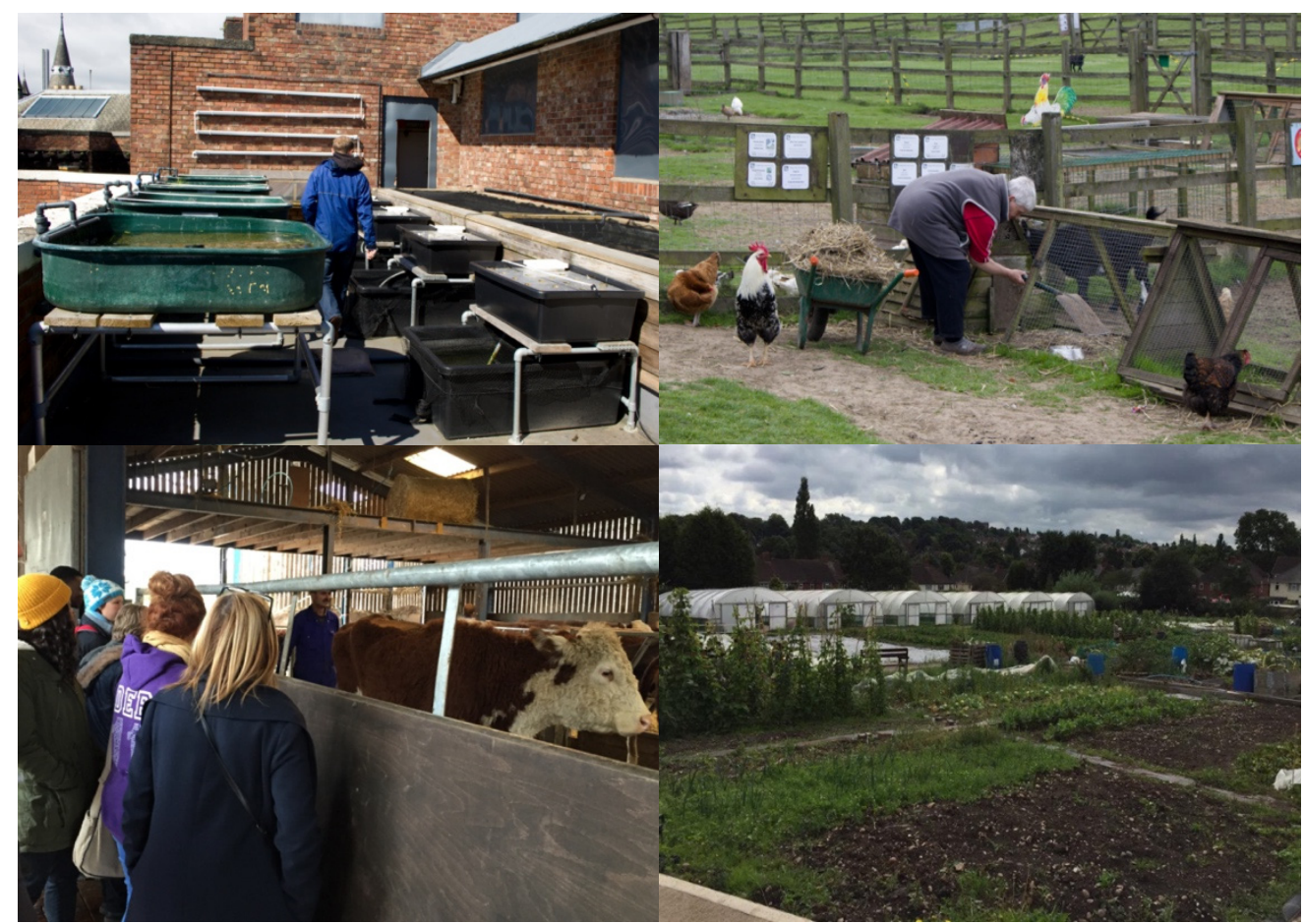

Figure 1. An overview of some of the urban farms explored in 2018 and 2019. Clockwise from top left-Farm Urban, Woodgate Valley Urban Farm, Wythenshawe Urban Farm, Salop Drive.

The previously mentioned Northern Roots model shows that appetite for this practice, with a share of $£ 24.5$ million recently being announced to support the scheme [44]. Northern Roots is located in Oldham, Greater Manchester, which is one of the most deprived towns in the country [45]. The site extends to the peri-urban, which is often described as a messy space in which the rural meets the city [46]. Northern Roots was designed as a tool to reconnect these two spaces whilst also enabling a local food economy around the concept of UA. The Director mentions how the project aims to 'transform' the food system in Oldham, allowing for the creation of a short food supply chain through UA. This is perhaps the first example of urban farming at scale which is being used as a major regeneration intervention in the UK.

As with Northern Roots, the rhetoric around urban farming is shifting, with a focus on sites being used as a tool for tackling inequalities in local food systems. One interviewee, however, cautions against over reliance on this approach, at the same time emphasizing that where urban farms are presented in this way they need to be properly supported: ' . . the idea that you can use urban farming as an answer to food poverty issues, I think you have to be very careful what you're saying there because food is a human right, the state needs to provide healthy, affordable food to its citizens and that's not through voluntaryrun, struggling, small food projects' (local authority planner). The interviewee highlights a common theme across all the urban farms explored; despite these spaces being large in terms of UA, in the context of the wider food system they are small-scale and often hyper local.

In all cases, the urban farmers and experts agreed that there has been a rise in interest in the practice, alongside direct investment. The Director of Social Farms and Gardens, who was interviewed as part of this study, argued that whilst there has been more interest, there are still issues with funding and the sustainability of schemes: 'funding is difficult ... funders often want new things and there is a lot of competition' (Director of Social 
Farms and Gardens). In this sense, he argues that there is more support, but it is perhaps not suited to the urban farming community because it can stifle collaboration in favor of competition. The Director continues to explain that 'there are more policy councils and food charters, which is good to see, but we don't know enough about their impact yet'. Here, the Director is referring to the formal tools which now exist and the recognition of the practice in formal policy and decision-making circles. Evidence suggests that food charters and policy councils can have a major impact on advancing UA, as has been shown in North America for instance [47].

Adding to this insight, an expert who has coordinated an urban farm for the majority of her life explained that 'we lived from grant to grant ... workers went and came, it was very unhealthy'. The other experts interviewed, from the planner to leading figures in urban farming in the UK, also agreed with the temporary nature of funding. In some cases, it was mentioned how urban farms would refuse to work together due to limited pots of funding: 'there's only so much money, you want to work with people but it's very political' (Urban Farm Social Enterprise Lead). These comments correlate well with the wider qualitative material and literature base, showcasing how the politics and funding involved in urban farming can often prevent the sharing of good practice, resources and other forms of collaboration.

\subsection{Financial Barriers to Practice}

Our investigation centered on barriers to upscaling urban farming and replicating the spectrum of practices explored more widely. Core barriers cited in the interviews ranged from financial constraints to vandalism. Perhaps the largest barrier cited was the initial bureaucracy involved in starting the farms, with all interviewed mentioning the excessive paperwork, insurance and financial elements as some of the major issues they encountered. Evidence shows that this has resulted in a number of UA activists adopting an informal approach, due to the barriers encountered at the beginning of their journeys [48].

Initial evidence shows that this alternative approach to UA has risen pre and postCOVID, resulting in 'guerrilla gardeners' and other informal actors colonising land without permission [48]. Indeed, several interviewees mentioned the informal approach and how this can be large-scale: 'our urban farm originally started through what you'd call guerrilla gardening. We had no choice, funding was tight' (Urban Farm Social Enterprise Lead), 'we started guerrilla gardening in the town center ... the urban farm developed from this' (Incredible Edible city lead). Evidently, an informal approach negates soil testing, risk assessments and other important processes linked to the establishment of a formal urban farm structure, potentially putting people in danger if crops are grown for consumption.

In terms of the sites explored here, all projects cited similar barriers and explicitly mentioned soil conditions as a major issue: 'soil testing is expensive' (Salop Drive), 'we worked with the university as it was the only way' (Wythenshawe Community Farm). In this sense, risk averse soil guidelines were blamed for increased costs, due to background levels of lead or other contaminants in the soil often exceeding soil screening values used in generic risk assessment for allotment sites; testing was also mentioned as an expensive cost at the start of operations, particularly where bioaccessibility studies are conducted. Adding to this, soil remediation and other tools can be expensive, resulting in this not being a serious option for many UA sites due to the immense costs involved [38]. Even more affordable mitigation measures, such as raised beds, are often comparably expensive given the funding limitations and can also reduce productivity, resulting in severe restrictions for UA projects aiming to farm at scale [4]. There are also issues around residents complaining about raised beds, particularly on open land. Economic modelling of UA demonstrates the financial burden if soil quality is identified as a barrier, with start-up costs often higher and yield lower, undermining the financial sustainability of these projects [45]. Maintenance of the raised beds can also be an issue, along with exposure to poor weather conditions or pests, which are often cited as reasons why projects may need to reinvest in such infrastructure $[8,48]$. 
Perhaps the largest challenge mentioned during this investigation surrounded the general financial models of many urban farms:

'We mostly rely on grants from charities' (Salop Drive Market Garden)

'Given the funding environment, a lot of organizations will do what they can to raise funds, it's a very challenging environment' (Director of Social Farms \& Gardens)

'We just don't have time to keep writing bids, we only have a few staff members' (Urban Farm Social Enterprise Lead)

'Our income is below $£ 25,000$ a year ... our income from supporters and community, which is the donations box generally and one-off donations people might give us, some people give a couple of hundred pound here and there' (Woodgate Valley Urban Farm)

Box schemes, admission fees, festivals and consultancy were the main activities used to bring in income according to interviewees. The box scheme was by far the most popular, with projects distributing fresh vegetables to nearby houses. The Woodbank Urban Farm site operated an innovative 'cooperative model', which created a critical mass of farmers and linked with major organizations in the region: 'we sell produce to the University, it generates a lot of money for us each year' (Woodbank Urban Farm). This model, alongside their box scheme and social prescription activities, resulted in multiple income streams to the site. Adding to this, they also operated an urban farmer training program which generated more revenue for operations and staff.

Woodgate Valley Urban Farm used to rely on donations but now charges an entry fee of $£ 1$, reportedly due to 'public donations being insufficient'. An element which connected all the farms investigated was that they employed people and had a substantial pool of volunteers. However, they all varied with how many and who was employed: the majority employed one central individual and then relied mostly on the volunteers for the wider working of the spaces. Volunteers were involved not only with practical tasks on the farms, but also with coordination and more skilled administrative tasks such as the treasurer role.

A unique feature of the Northern Roots site was its business model, which relies on a mosaic of activities to supplement the urban farm. In doing so, it avoids much of the sustainability issues identified above; ensuring that revenue is generated through more than just the sale of produce or visitor fees. In this sense, the model connects well with that of the Woodbank Urban Farm and shows how through not relying on one source of income, sites can be more secure and successful. Perhaps most notably for this paper, the scheme has received a large amount of financial support, demonstrating the interest in upscaling this concept [44]. This demonstrates again the support and desire for upscaled UA, which in this case is viewed as a transformation project for the region. Another unique element of Northern Roots was the data-driven decision-making process, with crop selection and other assets being decided on the basis of primary and secondary materials collected from other sites. Urban farms which adopt this approach, with solid plans and business models, often survive for longer [9].

\subsection{Soil Contamination Barriers}

A core theme emerging from the interviews surrounded the lack of space to expand activities. Several projects cited the issue of soil quality being a barrier and having to use raised beds or bid for funds to enable soil remediation. Projects, such as Salop Drive, Woodgate Valley Urban Farm, Wythenshawe Community Farm and Woodbank Farm, had invested revenue in soil remediation activities or involved other methods to be able to expand production and operations. This empirical material links well with the literature base, with [6] showing how even temporary UA projects can be costly due to issues around soil quality.

All sites interviewed cited soil contamination related to excessive lead $(\mathrm{Pb})$ concentrations at the beginning of their activities and often a need for raised beds or significant investment to remediate their sites. Many sites also cited issues around accessing soil scientists or expertise, due to over-stretched local authority budgets and a lack of knowledge 
around where to access such resources. Several urban farms turned to private companies, who often charged a premium for basic data. In all cases, soil was viewed as a barrier, not merely due to contamination, but also due to the financial barriers with understanding the quality of the land in the first place. In this sense, projects struggled to often undertake soil sampling, which is required for risk assessment, insurance and planning permission.

In the context of Northern Roots, and in a similar manner to the wider qualitative exploration of other urban farms, our initial pilot work revealed that lead levels on the proposed location were high in nature, with the local contamination officer advocating for the use of raised beds. Despite no previous industrial activity taking place at the location, the background lead $(\mathrm{Pb})$ levels and risk averse guidelines resulted in higher start-up costs for the program. As $[49,50]$ argue, lead $(\mathrm{Pb})$ is often a major obstacle to UA activities and can result in projects being refused permission or being provided with certain restrictions which can be costly. The Northern Roots project was able to work with our institution and use specialist funds to support investigations, alongside mitigation measures to enable the UA project to develop.

\subsection{Crime and Urban Farming}

A major concern with any form of UA surrounds crime, particularly the larger scale activity such as urban farming, with expensive equipment and other valuable assets usually left on-site. With one case study, Wythenshawe Community Farm, this has resulted in animals being killed and equipment being stolen. Other urban farms visited reported minor issues, whilst some had gone to extreme lengths, such as Woodgate Valley Urban Farm's CCTV system in Figure 2. The majority of interviewees felt that vandalism was prevalent in the early days of their farms, but note that once residents were more used to the facility, it decreased: 'they were a bit taken back by it at first, but once they knew it was for them then it all stopped' (Salop Drive).

Such security systems are costly and add to the running of the farms. As with most forms of UA, vandalism is expected, although involving the community as much as possible can help to prevent some of this from occurring. In New York City for instance, UA in the Bronx and other disadvantaged areas benefitted, in terms of security, from the local authority involving younger people from the community, since this resulted in them taking ownership and protecting the space [9]. Similar tactics were echoed by interviewees as part of this study, with the Wythenshawe site highlighting how involving younger people has perhaps prevented future issues: 'we have a regular growing club and involve the schools as much as possible ... they love it'.

The urban farming expert interview group echoed the views of the site discussions, with many having experienced or heard of crime affecting operations. An Incredible Edible city lead, interviewed as part of the study, highlighted how 'plants were taken root and all ... we've had equipment stolen and sheds broken into'. With vandalism often occurring at the beginning of operations, this appears to put even more pressure on these sites, with budgets already stretched due to soil testing and other important procedures. When upscaling UA, our study shows that it is important to be conscious of these potential hurdles and to add mitigation measures if possible. As [1] shows however, mitigation measures can be extremely expensive and are not possible for all UA sites. 


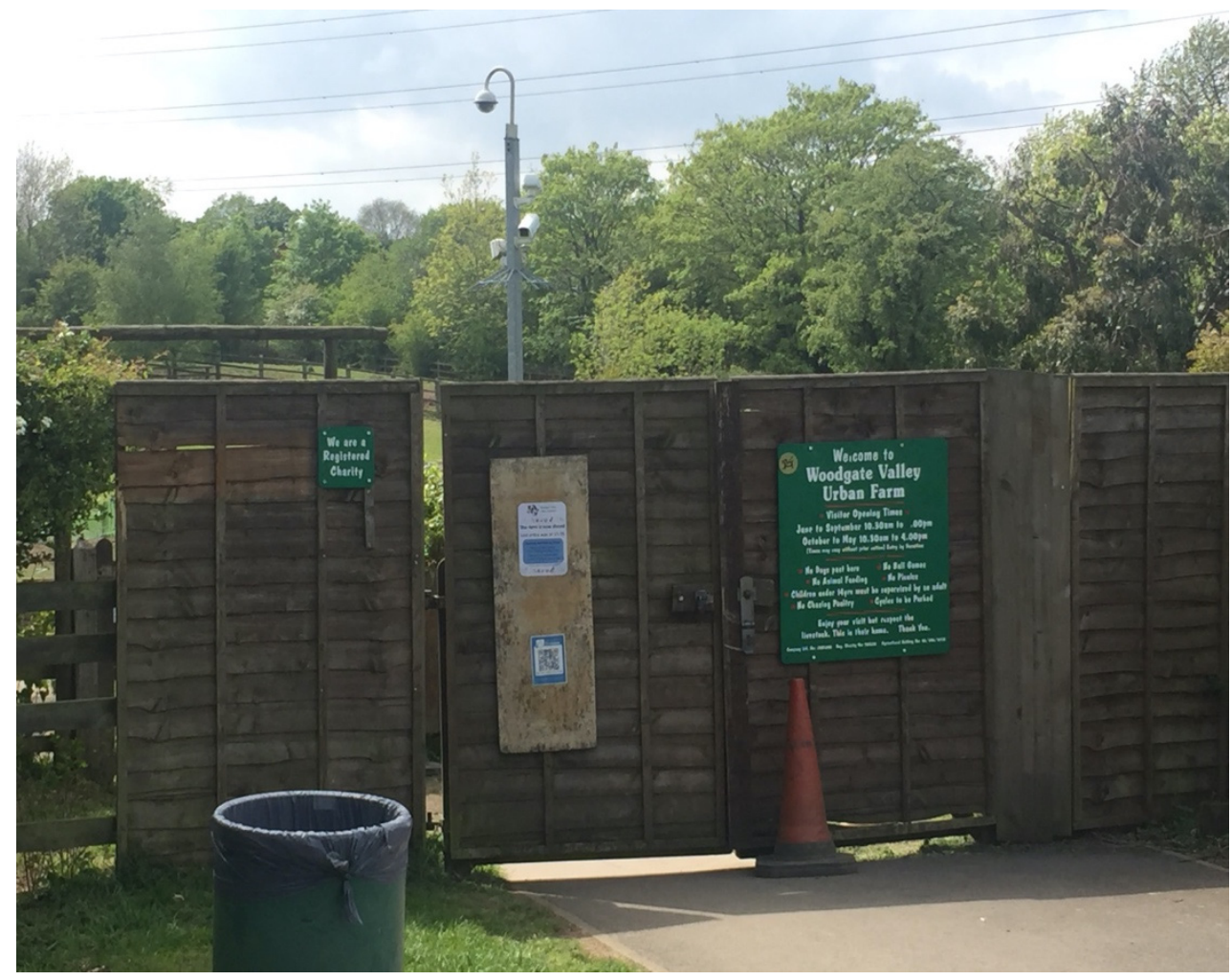

Figure 2. CCTV systems installed at an urban farm experiencing vandalism.

\subsection{Opportunities with Urban Farming}

As [50] notes, urban farms act as important hubs in enabling city-wide UA. They act as catalysts, connectors for smaller sites and are important assets within inner-urban communities [25]. The Director of Social Farms \& Gardens noted how 'urban farms are immensely important and provide services right in the heart of deprived areas'. This is echoed by the urban farms visited as part of this research, with many employing local people, enabling communities to access fresh produce and creating short-food supply chains. In all cases, it was noted that a local connection was important to sustain activities:

'Lots of local people get involved and volunteer' (Woodbank Urban Farm)

'We have individual allotments or programs for local people to get involved with on the space' (Salop Drive)

'We've worked with the local community for years ... there are lots of younger and older people involved' (Woodgate Valley Urban Farm)

‘We have a growing club every Wednesday afternoon with lots of local people turning up to join in and learn' (Wythenshawe Community Farm)

Beyond the value to local communities, experiences during the COVID-19 pandemic demonstrated the immense value of these projects in terms of the ways in which they were able to respond to issues in the supply chain. During the pandemic, Farm Urban and The Kindling Trust upscaled production to mitigate issues in the conventional food system, particularly during lockdowns in the UK. With the former, Farm Urban were able to use their vertical growing systems to generate fresh produce for communities in need in Liverpool. This demonstrates the potential of urban farms to add value to the existing food system, particularly in times of need. Evidence shows that other UA spaces acted in a similar manner, with the likes of community gardens, allotments and other spaces adding value through increased production or virtual classes to encourage others to grow $[51,52]$.

Our study showed that the vast majority of urban farms investigated are now involved in social prescribing. These spaces are now providing an opportunity for referrals from local 
health services, with a large array of studies showing that they can significantly impact on the health and wellbeing of participants [13]. The authors continue to argue that care farms and wider UA practices can be vital tools in reducing hospital admissions and reducing General Practice (GP) appointments [13]. In the context of this study, 4 out of the 5 core urban farms explored had formal social prescribing initiatives. The concept lends itself more to traditional urban farms, particularly the market garden and social farm models explored as part of this research. A major restriction on newer 'radical' models, such as Farm Urban, is the potential lack of an opportunity to incorporate social prescription; with high-tech projects often highly automated and in inaccessible spaces, this does not fit as well with the social prescription model.

The wider urban farm expert group also reinforced this idea that social prescribing is popular in the large-scale UA community: 'we work with older people and younger people, particularly with mental health issues' (Urban Farm Social Enterprise Lead), 'we generate some money through Age Concern UK' (Incredible Edible city lead). The Director of Social Farms \& Gardens agrees with this view, stating that he has witnessed a rise in UA sites offering formal and informal social prescription. The Head Gardener at Salop Drive Market Garden cited this as a core source of income, but also the way in which the schemes make the largest impact to its local population; offering services for the vulnerable, fresh produce and a space for socialization. The importance of these assets was echoed by other interviewees, who noted how this can increase the value of urban farms in communities whilst also enabling them to be more financially secure. This is backed up by data from elsewhere, particularly [11]'s social value research into the practice.

Our reflections here showcase how urban farming is now presenting opportunities beyond the social, but is now witnessing a shift to focusing around the health agenda and supplementing the wider food system. With the latter, the recent developments during COVID have shown the immense potential of urban farming and how short-food supply chains can have a meaningful impact in communities. The popularity of social prescribing is described as a 'win win' for projects by the Director of Social Farms \& Gardens. In this sense, further demonstrating their value to communities whilst enabling another income stream into projects. However, as the Director notes again, social prescription schemes need compete for funding and there is a danger that this could once again impact on collaboration between schemes.

\subsection{Contributions to Knowledge: Reviewing the Key Findings}

The qualitive findings provide an in-depth review of the core opportunities and barriers to urban farming practice. In order to make the contributions of this paper explicit, Table 2 provides an overview of the meta challenges and opportunities linked to each typology from the combined secondary and primary data:

Table 2 is not an exhaustive list, but rather an overview of the major opportunities and barriers stemming from our investigation. A cross-cutting barrier is that of vandalism, which plagues the urban farming movement, regardless of the form of activity. The other major issue surrounds the financial models, particularly the capital costs and issues around revenue generation. In this context, we argue that a model which involves a mosaic of activities can lead to more sustainable urban farms. Northern Roots is a good example here from our study, in which a combination of the sale of produce, traineeship schemes, social prescribing initiatives, bee-keeping and other activities combine to ensure revenue is generating through multiple sources. On a smaller-scale, The Kindling Trust is an exemplar from our study to demonstrate that this can be done successfully within more 'traditionally sized' urban farms too.

Through Table 2, which is informed by our primary and secondary data, we hope to raise awareness amongst practitioners, policy-makers and other officials other the positive and negatives of varying forms of urban farming. With post-COVID policy and funding investing heavily in this area, our qualitative study aimed to draw on a range of perspectives of urban farmers and key actors to provide details on the realities of operating such spaces 
on the ground. Through combining this with the wider desktop work, we provide a balance between the subjective opinions and wider objective observations of each model. In doing so, we hope to help inform decision-making around the concept and enable urban farming models which are more sustainable and appropriate for the communities in which they are situated.

Table 2. Core opportunities and barriers of different forms of urban farming.

\begin{tabular}{|c|c|c|}
\hline Typology & Opportunities & Barriers \\
\hline High-tech urban farms & $\begin{array}{ll}\text { - } & \text { Increased yield in small spaces } \\
\text { - } & \text { Experimentation with new varieties } \\
\text { - } & \text { Water-saving measures of some systems }\end{array}$ & $\begin{array}{ll}\text { - } & \text { Large start-up and running costs } \\
\text { - } & \text { Energy use concerns } \\
\text { - } & \text { Lack of social value (e.g., connection with } \\
\text { communities) }\end{array}$ \\
\hline $\begin{array}{l}\text { Market gardens / } \\
\text { cooperative farms }\end{array}$ & $\begin{array}{l}\text { - High levels of social value, particularly } \\
\text { for nearby communities } \\
\text { - } \quad \text { Social enterprise or business creation } \\
\text { - } \quad \text { Apprenticeships and other formal train- } \\
\text { ing schemes }\end{array}$ & $\begin{array}{l}\text { - } \quad \text { Land availability and soil quality } \\
\text { - Access to utilities (e.g., water supply and } \\
\text { facilities for workers/volunteers) } \\
\text { - } \quad \text { Limited revenue generation }\end{array}$ \\
\hline Social farms & $\begin{array}{l}\text { - Can relieve pressure from conventional } \\
\text { health services } \\
\text { - } \quad \text { Innovative revenue generation } \\
\text { - } \quad \text { Targeted care for often vulnerable groups }\end{array}$ & $\begin{array}{l}\text { - High-level of expertise needed for staff (e.g., } \\
\text { animal care or medical backgrounds) } \\
\text { - } \quad \text { Strict regulations and accreditation processes } \\
\text { - } \quad \text { Irregular funding in some cases }\end{array}$ \\
\hline $\begin{array}{c}\text { Large-scale (>50 acres) } \\
\text { urban farms }\end{array}$ & $\begin{array}{l}\text { - Potentially transformative, enabling } \\
\text { short food supply chains } \\
\text { - } \quad \text { Large employment opportunities } \\
\text { - } \quad \text { Revenue generation through visitors } \\
\text { and residents }\end{array}$ & $\begin{array}{l}\text { - High capital costs and large amount of land } \\
\text { required } \\
\text { - } \quad \text { Large failure rate due to experimental nature } \\
\text { - } \quad \text { Political buy-in often hard to achieve }\end{array}$ \\
\hline
\end{tabular}

\section{Moving Forwards}

Our study provides evidence of the new opportunities linked to urban farming, but also the barriers preventing the upscaling of practice. Core issues around economic sustainability, soil quality and vandalism continue to plague projects. Barriers around soil were continually cited in the qualitative material, with projects frustrated or often confused with how to obtain data and overcome obstacles. As our results demonstrate, even the most ambitious of projects encounter issues related to soil quality, which in turn can prevent the sites from releasing their full potential. This is demonstrated in our reflections of Northern Roots, which despite generating significant funding, faces similar issues to other urban farms interviewed as part of this project. There is a danger here that, by restricting large-scale UA activities, this could have a wider detrimental impact on the wider productive cityscape: reducing the opportunity for care activities, adding costs to overwhelmed projects and hampering progress. There are also issues around accessing expertise on soil sampling, due to the cost implications of such activity.

In this sense, we call for key actors to consider supporting UA sites to understand soil quality, either through funding or existing links with Higher Education Institutions, who can often center student projects or provide more cost-effective solutions, see for example, [53]. We also call for more start-up funding and support to enable groups to pursue a more formal agenda to UA; learning lessons from good practice and avoiding mistakes which could impact on the sustainability of their venture. In terms of practitioners, we call for a more data-drive approach, through using resources to understand the market opportunities and revenue streams, thus avoiding issues around failure, due to the business model employed. Moving away from the grant model would be ideal, avoiding the issues identified in Section 2. 
Overall, it is clear the upscaled urban farming is of immense value to cities. These spaces offer significant social, environmental and economic benefits. With the recent rise in farms offering social prescription, this adds yet another layer of value and could potentially allow for pressure to be removed from conventional health care systems (see for example, [13]). As more sites are created in the Global North and South, we call for more research into the concept and to highlight good practices. In this sense, allowing for others to learn from lessons, avoid costly mistakes and to realize the benefits of urban farming at scale.

Author Contributions: Funding acquisition was through all three authors. M.H. and A.C. with Oldham Council and M.H. and G.S. with Pendleton Cooperative. All authors have read and agreed to the published version of the manuscript.

Funding: This research was partly funded by Oldham Council and the Pendleton Cooperative.

Institutional Review Board Statement: The study was conducted in accordance with the Declaration of Helsinki, and approved by the University of Salford's ethics board (2017, 2018 and 2019 for both the Oldham and Pendleton funding).

Informed Consent Statement: Informed consent was obtained from all subjects involved in the study.

Data Availability Statement: Qualitative data has been anonymized for the protection of participants. Interview transcripts are not open access, due to the informed consent process.

Acknowledgments: We would like to acknowledge the support of the local authorities involved, communities and urban farmers who gave up time to be interviewed.

Conflicts of Interest: The authors declare no conflict of interest.

\section{References}

1. St Clair, R.; Hardman, M.; Armitage, R.P.; Sheriff, G.S. The Trouble with Temporary: Impacts and Pitfalls of Meanwhile Community Gardening in Wythenshawe, South Manchester. Renew. Agric. Food Syst. 2017, 33, 548-557. [CrossRef]

2. Tornaghi, C.; Certoma, C. Urban Gardening as Politics; Routledge: London, UK, 2019.

3. Nasr, J.L.; Komisar, D. The Integration of Food and Agriculture into Urban Planning and Design Practices. In Sustainable Food Planning: Evolving Theory and Practice; Viljoen, A., Wiskerke, J.S.C., Eds.; Wageningen Academic Publishers: Wageningen, The Netherlands, 2012.

4. Caputo, S. The Purpose of Urban Food Production in Developed Countries. In Sustainable Food Planning: Evolving Theory and Practice; Viljoen, A., Wiskerke, J.S.C., Eds.; Wageningen Academic Publishers: Wageningen, The Netherlands, 2012.

5. Holland, L. Diversity and Connections in Community Gardens: A Contribution to Local Sustainability. Local Environ. Int. J. Justice Sustain. 2004, 9, 285-305. [CrossRef]

6. St Clair, R.; Hardman, M.; Armitage, R.P.; Sheriff, G.S. Urban agriculture in shared spaces: The difficulties with collaboration in an age of austerity. Urban Stud. 2020, 57, 350-365. [CrossRef]

7. Social Farms \& Gardens. COVID-19 Impact Survey. 2021. Available online: https:/ /www.farmgarden.org.uk/news/covid-19 -impact-update-survey-launched (accessed on 6 September 2021).

8. Hardman, M.; Larkham, P. Food Charters: A Mechanism for Increasing Urban Agriculture. Land Use Policy 2014, 39, 400-402. [CrossRef]

9. Hardman, M.; Larkham, P. Informal Urban Agriculture: The Secret Lives of Guerrilla Gardeners; Springer: London, UK, 2014.

10. Mead, B.R.; Davies, J.A.C.; Falagan, N.; Kourmpetli, S.; Liu, L.; Hardman, C.A. Urban Agriculture in Times of Crisis: The Role of Home Food Growing in the Perceived Food Insecurity and Well-Being during the Early COVID-19 Lockdown. Emerald Open Res. 2021, 3, 105508. [CrossRef]

11. Schoen, V.; Caputo, S.; Blythe, C. Valuing physical and Social Output: A Rapid Assessment of a London Community Garden. Sustainability 2020, 12, 5452. [CrossRef]

12. Social Farms and Gardens. Scale of the Sector. 2020. Available online: https://www.farmgarden.org.uk/gcf/scale-of-sector (accessed on 7 June 2021).

13. Howarth, M.L.; Brettle, A.J.; Hardman, M.; Maden, M. What is the evidence for the impact of gardens and gardening on health and wellbeing: A scoping review and evidence-based logic model to guide healthcare strategy decision making on the use of gardening approaches as a social prescription. BMJ Open 2020, 10, e036923. [CrossRef]

14. DEFRA. Green Social Prescribing. 2021. Available online: https://www.gov.uk/government/publications/green-socialprescribing-call-for-expressions-of-interest/green-social-prescribing-call-for-expressions-of-interest (accessed on 6 June 2021).

15. Esmee Fairbairn Foundation (N.D.). Nature Friendly Farming. Available online: https:// esmeefairbairn.org.uk/our-aims/ournatural-world/farming/ (accessed on 1 December 2021). 
16. Big Lottery Community Fund. Almost $£ 20$ million in National Lottery Funding to Support UK Communities to Tackle Climate Change. 2020. Available online: https:/ /www.tnlcommunityfund.org.uk/news/press-releases/2020-12-01/almost-20-millionin-national-lottery-funding-to-support-uk-communities-to-tackle-climate-change (accessed on 2 May 2021).

17. Green Future Associates (N.D.). Urban Agriculture Consortium. Available online: https://www.greenfuture.org.uk/urbanagriculture-consortium/ (accessed on 1 December 2021).

18. Al-Chalabi, M. Vertical Farming: Skyscraper Sustainability? Sustain. Cities Soc. 2015, 18, 74-77. [CrossRef]

19. Hydroponics Society of America (N.D.). About the Hydroponics Society of America. Available online: http://www. hydroponicsocietyofamerica.org/ (accessed on 2 September 2021).

20. Yanes, A.R.; Martinez, P.; Ahmad, R. Towards Automated Aquaponics: A Review on Monitoring, IoT and Smart Systems. J. Clean. Prod. 2020, 263, 121571. [CrossRef]

21. Farm Urban (N.D.). Food for the Future for Everyone. Available online: https://farmurban.co.uk/ (accessed on 3 May 2021).

22. De Oliveira, F.B.; Forbes, H.; Schaefer, D.; Millsavljevic-Syed, J. Lean Principles in Vertical Farming: A Case Study. Procedia CIRP 2020, 93, 712-717. [CrossRef]

23. Chipungu, L.; Magidimisha, H.; Hardman, M.; Beesley, L. Exploring Urban Agriculture in Africa: A Review of the Practice in Harare, Nairobi and Johannesburg. In Land-Use Change Impacts on Soil Processes in Tropical and Savannah Ecosystems; Thomas, A., Brearley, F., Eds.; CABI: Surrey, UK, 2015.

24. Hardman, M.; Chipungu, L.; Hangwelani, M.; Larkham, P.J.; Scott, A.J.; Armitage, R.P. Guerrilla Gardening and Green Activism: Rethinking the Informal Urban Growing Movement. Landsc. Urban Plan. 2018, 170, 6-14. [CrossRef]

25. Chenarides, L.; Grebitus, C.; Lusk, J.L.; Printezis, I. Who Practices Urban Agriculture? An Empirical Analysis of Participation Before and During the COVID-19 Pandemic. Agribusiness 2020, 37, 142-159. [CrossRef] [PubMed]

26. Carolan, M. Urban Farming is Going High Tech: Digital Urban Agriculture's Links to Gentrification and Land Use. J. Am. Plan. Assoc. 2020, 86, 47-59. [CrossRef]

27. De Oliveira, F.B.; Ferson, S.; Dyer, R. A Collaborative Decision Support System Framework for Vertical Farming Business Developments. Int. J. Decis. Support Syst. Technol. 2021, 13, 34-66. [CrossRef]

28. Bisospheric Foundation (N.D.). Biospheric Foundation Circa 2013-2015. Available online: http:/ / www.biosphericfoundation. $\mathrm{com} /$ (accessed on 15 November 2021).

29. Wigan Today. College Vertical Farm to Feed the Homeless. 2016. Available online: https://www.wigantoday.net/news/collegevertical-farm-help-feed-homeless-751488 (accessed on 14 December 2021).

30. Northern Roots (N.D.). Grown in Oldham. Available online: https://northern-roots.uk/ (accessed on 1 April 2021).

31. Oldham Chronicle. Northern Roots Secures Towns Fund. 2021. Available online: https://www.oldham-chronicle.co.uk/newsfeatures /139/main-news/141805/northern-roots-appoints-awardwinning-architects-and-secures-funding-from-towns-fund (accessed on 6 September 2021).

32. Northern Roots. Growing Northern Roots. 2020. Available online: https://northern-roots.uk/the-northern-roots-story/growingnorthern-roots / (accessed on 6 December 2021).

33. Zheng, Y.; Weng, Q. Modeling the Effect of Green Roof Systems and Photovoltaic Panels for Building Energy Savings to Mitigate Climate Change. Remote Sens. 2020, 12, 2402. [CrossRef]

34. Barriuso, F.; Urbano, B. Green Roofs and Walls Design Intended to Mitigate Climate Change in Urban Areas across All Continents. Sustainability 2021, 13, 2245. [CrossRef]

35. Orsini, F.; Dubeling, M.; De Zeeuw, H.; Gianquinto, G. Rooftop Urban Agriculture; Springer: London, UK, 2017.

36. Diehl, J.A.; Sweeney, E.; Wong, B.; Sia, C.S.; Yao HPrabhudesai, M. Feeding Cities: Singapore's Approach to Land Use Planning for Urban Agriculture. Glob. Food Secur. 2020, 26, 100377. [CrossRef]

37. The Independent. Rare Orchids to Flood Resilience: How Can Green Roofs Help to Tackle the Climate and Nature Crises? 2021. Available online: https://www.independent.co.uk/climate-change/news/green-roofs-climate-nature-crises-b1872939.html (accessed on 6 July 2021).

38. Nadal, A.; Ceron-Palma, I.; Perez-Sanchez, M.; Rodriguez-Labajos, B.; Cuerva, E.; Josa, A.; Rieradevall, J. Social Perception of Urban Agriculture in Latin American: A Case Study in Mexian Social Housing. Land Use Policy 2018, 76, 719-734. [CrossRef]

39. Drescher, A.W.; Isendahl, C.; Caridad-Cruz, M.; Karg, H.; Menakanit, A. Urban and Peri-Urban Agriculture in the Global South In Urban Ecology in the Global South; Shackleton, C.M., Cilliers, S.S., Davoren, E., du Toit, M.J., Eds.; Springer: London, UK, 2012.

40. Caputo, S.; Rumble, H.; Schaefer, M. "I Like to Get my Hands Stuck in the Soil": A Pilot Study in the Acceptance of Soil-Less Methods of Cultivation in Community Gardens. J. Clean. Prod. 2020, 258, 120585. [CrossRef]

41. Hanson, D.; Marty, E.; Hanson, M. Breaking through Concrete: Building an Urban Farm Revival; University of California Press: Berkley, CA, USA, 2012.

42. Silverman, D. Doing Qualitative Research; Sage: London, UK, 2017.

43. Mitchell, L.; Houston, L.; Hardman, M.; Cook, P.; Howarth, M.L. Enabling Urban Social Farming: The Need for Radical Green Infrastructure in the City. Cogent Soc. Sci. 2021, 7, 1976481. [CrossRef]

44. Manchester Evening News. Oldham Gets £24.5 Million Government Cash for Four Huge Town Centre Projects. 2021. Available online: https:/ / www.manchestereveningnews.co.uk/news/greater-manchester-news/oldham-gets-244m-government-cash20778178 (accessed on 7 December 2021). 
45. Scott, A.J.; Carter, C.; Larkham, P.; Reed, M.; Morton, N.; Waters, R.; Adams, D.; Collier, D.; Crean, C.; Curzon, R.; et al. Disintegrated Development at the Rural Urban Fringe: Re-connecting Spatial Planning Theory and Practice. Prog. Plan. 2013, 83, 1-52. [CrossRef]

46. Northern Roots. Community Food Growing Project. 2021. Available online: https://northern-roots.uk/get-involved/ community-food-growing-project/ (accessed on 10 January 2022).

47. Shapiro, L.F.; Hoey, L.; Colasanti, K. Stories as Indicators: Lessons Learned Using the Most Significant Change Method to Evaluate Food Systems Work in Michigan. J. Agric. Food Syst. Community Dev. 2021, 10, 399-411.

48. Environment Agency (N.D.). What's in Your Backyard? Available online: https://www.apps.environment-ahency.gov.uk/ wiyby / default.aspx (accessed on 7 January 2022).

49. Brown, S.L.; Chaney, R.L.; Hettiarachchi, G.M. Lead in Urban Soils: A Real or Perceived Concern for Urban Agriculture? J. Environ. Qual. 2016, 45, 26-36. [CrossRef] [PubMed]

50. EULP Blueprint (N.D.). Best Practice; What's in Your Backyard? Available online: https://joinup.ec.europa.eu/collection/eliseeuropean-location-interoperability-solutions-e-government/solution/eulf-blueprint/best-practice-4 (accessed on 6 July 2021).

51. Dennis, M.; Beesley, L.; Hardman, M.; James, P. Ecosystem (dis) Benefits Arising from Formal and Informal Land-Use in Manchester, UK: A Case Study of Urban Soil Characteristics Associated with Local Green Space Management. Agronomy 2020, 10, 552. [CrossRef]

52. Schoen, V.; Blythe, C. COVID-19: A Growing Opportunity for Community Gardening in London. 2020. Available online: https:/ / ruaf.org/region/europe/ (accessed on 8 December 2021).

53. Washington State University (N.D.). Stable Isotope Core Laboratory. Available online: https://labs.wsu.edu/isotopecore/ (accessed on 7 December 2021). 